\title{
THE CONTENTS
}

\section{List of Illustrations p.ix \\ Introduction p.xi}

p.I Chapter One

Medical Conditions in Pre-Islamic Arabia and in the Umayyad Period

p.7 Chapter Two

The Age of the Translations

Greek works p.8

Syriac works p.15

Persian works p.I6

Indian works p.I9

The consequences p.20

Erratic blocks p.24

The elaboration of a scientific terminology p.27

The Islamization of certain Greek tenets p.30

The recovery of lost Greek texts p.3 I

p.4I Chapter Three

Survey of the History of Arabic Medicine

The influence of Arabic medicine on the West p.52

p.55 Chapter Four

Physiology and Anatomy

The elements p. 56

The temperament p. 57

The four humours P. 57

The faculties $\mathrm{p} .60$

The pneumata p.62

Recapitulation p. 63

The movement of the blood p.64

Anatomy p.70 


\begin{tabular}{|c|c|}
\hline p. 72 & $\begin{array}{l}\text { Chapter Five } \\
\text { Pathology }\end{array}$ \\
\hline p.86 & $\begin{array}{l}\text { Chapter Six } \\
\text { The Transmissibility of Illnesses and the Plague }\end{array}$ \\
\hline p.97 & $\begin{array}{l}\text { Chapter Seven } \\
\text { Dietetics and Pharmaceutics } \\
\text { Dietetics p.97 } \\
\text { Pharmaceutics p.ro3 }\end{array}$ \\
\hline p.107 & $\begin{array}{l}\text { Chapter Eight } \\
\text { Medicine and the Occult } \\
\text { Medicine and astrology p.I I I }\end{array}$ \\
\hline & Abbreviations p.I I 5 \\
\hline & Notes p.II7 \\
\hline & Index p.I3I \\
\hline
\end{tabular}

